\title{
Medyada Kadın Cinayeti Haberlerindeki Cinsiyetçi İzler: Radikal Gazetesi
}

\author{
Songül Sallan Gül' \\ Yonca Altındal ${ }^{2}$
}

\begin{abstract}
Öz
Kadın çalışmaları literatüründe "femicide" olarak kullanılan kadın cinayeti olgusu, kadınların, kadın olmalarından dolayı eril şiddet yoluyla öldürülmelerini ifade etmektedir. Kadınlar başta eşleri, eski eşleri, birlikte olduğu erkekler gibi en yakınlarındaki ya da hiç tanımadıkları erkekler tarafından cinayete kurban gitmektedir. Kadın bedeni ve cinselliği üzerindeki eril denetim ve tahakküm, şeref ve namus adı altında evlilikte ve kamusal alanda kadınların ölümlerine neden olmaktadır. Öyle ki dünya genelinde her yıl yaklaşık 66.000 kadın öldürülmektedir. Türkiye'de de son on iki yılda 1.246, son bir yılda da 300'e yakın kadın cinayeti işlenmiştir. Kadın cinayetlerinin faillerinin büyük çoğunluğunun akraba erkekler olması, ataerkil toplumsal yapı ve değerlerle onları yeniden üreten mekanizmaları sorgulamayı gerekli kılmaktadır. Ulaştığı kitlenin yaygınlığı ve ileri teknoloji dolayısıyla yazılı ve görsel medya bunlardan birisidir. Kadın cinayetlerine ilişkin haberlerde kullanılan üslup, semboller, işaretler, sayılar, sözcükler ve fotoğraflarla egemen eril değerler ile toplumsal cinsiyet düzeni yeniden üretilmekte ve pekiştirilmektedir.
\end{abstract}

Bu makalede medyanın rolü Radikal gazetesi örneğinde ele alınmaktadır. İlk olarak dünyadaki ve Türkiye'deki görünümleriyle kadın cinayeti olgusu ve medya iliş̧isi sosyolojik olarak farklı boyutlarıyla değerlendirilmektedir. İkinci olarak Radikal gazetesinde 2013 yılında yayınlanan 79 aileiçi toplumsal cinsiyet temelli kadın cinayeti haberinin haber taşıma değeri ve haber yapma biçimi sorgulanmaktadır. Kadın cinayeti haberlerinin başlık ve metinleri içerik analizi tekniğiyle değerlendirilerek, Radikal gazetesi örneğinde medyada cinsiyet temelli ayrımcılığın ve cinsiyetçiliğin izleri sorgulanmaktadır. Kadın cinayetlerini sıradan, normal ve sansasyonel haberlere dönüştüren medyanın cinsiyetçi söylemi yeniden üretme biçimleri tartışılmaktadır.

Anahtar Kelimeler: Kadın cinayeti, toplumsal cinsiyet, medya, cinsiyetçilik, Radikal gazetesi

\section{Sexist Reflections in the News of Femicide on Media: Radikal Newspaper}

\begin{abstract}
The killing of women, known as 'femicide' in the women studies literature, refers to the killing of women by men just because of their gender. Women are murdered by their intimate male partners such as their husbands, ex-husbands or boyfriends or by men they do not know at all. Masculine hegemony and control on women's body and
\end{abstract}

1 Prof. Dr., Süleyman Demirel Üniversitesi, Sosyoloji Bölümü

2 Arş. Gör., Süleyman Demirel Üniversitesi, Sosyoloji Bölümü 
sexuality result in the killing of women at home and in the public area in the name of honour and chastity. Every year approximately 66,000 women are killed all around the world. In Turkey, 1,246 women were murdered in the last twelve years and 300 of them were killed in the last year. Since a great majority of the murderers are male relatives, there is a need to question patriarchal social and familial structures and the mechanisms reproducing them. Print and visual media are among these mechanisms due to its high-technology orientation and the size of masses they can reach. Media can reproduce and reinforce the patriarchal values and gender patterns through the use of symbols, signs, numbers, wordings, and photographs in the news regarding the killings of women.

This study examines the role of the media considering the example of Radikal Newspaper. First, the different aspects of the phenomena of femicide and media relations are evaluated sociologically through the national and global examples. Secondly, the newsworthiness and news making methods of 79 news reports published in Radikal Newspaper in 2013 regarding women killed as a result of domestic violence are reviewed. The headings and contexts of the news on femicide are analysed by content analysis method in order to see the signs of gender based violence and sexism in the print media. Furthermore, the methods regarding how media reproduce the sexist rhetoric by covering the killings of women in the news as sensational, ordinary or normal events are also discussed.

Keywords: Femicide, gender, media, sexism, Radikal Newspaper 


\section{Giriș}

1960'ı yıllarda kadına yönelik aileiçi şiddet olgusu, kadın hareketinin yoğun çabalarıyla birlikte özel alandan çıkarak, toplumsal ve politik gündemin belirleyicilerinden biri olmuştur. Kadına yönelik şiddetin en ağır ve ölümcül biçimi olan kadın cinayeti olgusu ise, 1976 yılında ilk kez Güney Afrikalı yazar Diana E. H. Russell tarafından, "femicide" olarak ifadelendirilmiş ve erkeklerin kadınları, kadın olmalarından dolayı öldürmeleri anlamında tanımlanmıştır. Namus, tutku, kıskançlık ve çeyiz cinayeti olarak da kullanılan kadın cinayeti olgusu, Amerika ve Orta Doğu ülkelerinde namus cinayeti, Güney Asya'da ise çeyiz cinayeti ve Afrika'da ise, öldürenin ceza bile almadığı 'cinayet' olarak kullanılmaktadır (Spinelli, 2011:17).

Pek çok ülkede ataerkil aile ve değerler sistemiyle kadınların yaşam hakları ellerinden alınmaktadır. Dünya genelinde her yıl yaklaşık 66.000 kadın, ataerkil yapı ve değerlerin bir yansıması olarak fiziksel ve çoğu kez de cinsel şiddetle iç içe geçerek, erkek şiddetiyle öldürülmektedir (WHO, 2002). Avrupa'da 2006 yılında kadın cinayetlerinin \%70'i ailede, eş ya da birlikte yaşadıkları erkekler tarafından gerçekleşmiştir. En çok kadın cinayeti işlenen ülkeler El Salvador ve Kolombiya olurken, Doğu Avrupa ile Rusya Federasyonu'nda da kadın cinayetleri kaygı verici düzeye ulaşmıştır. Yine yüz binde 6 ile Güney Amerika kadın cinayetlerinin en yüksek oranda olduğu kıta olurken, onu yüz binde 4 ile Kuzey Amerika, Orta Amerika ve Karayip Adaları izlemektedir. Benzer biçimde, kadına yönelik şiddet sonrasında intihar eden kadın oranları da artmaktadır. Avrupa'da 2006 yılında aile içi şiddet sonrasında intihar eden kadın sayısı 1.100 olmuştur. Amerika'da aile içi şiddet gören kadınların \%35-40'ı intihar girişiminde bulurken, AB ülkelerinde de bu oran \%42'lere kadar çıkmaktadır (SASRN, 2012:4).

Türkiye'de ise, kadın cinayetleri kavramı "namus, töre cinayetleri ya da namus suçları" olarak da adlandırılmış, töre ve namus cinayetleri dâhil, 2002'de 66 olan kadın cinayeti sayısı, 2013 yılında da 237'ye yükselmiştir (Sallan Gül ve Altındal, 2014). Son on iki yılda ülkemizde öldürülen kadın sayısı da toplamda 1.300'e ulaşmıştır. Türkiye'de 2013 yııında toplam 237 kadın cinayeti işlenirken, 2014 yılının ilk on ayında bu sayı 226’ya ulaşmıştır (Kadın Cinayetlerini Durduracağız Platformu, 2014).

Kadın cinayeti olgusu, uzun yıllar suç bağlamlı olarak güvenlik bakış açısıyla ele alınmış ve öldürülme vakası olarak değerlendirilmiştir. Kadın cinayetleri, cinayeti kimin işlediği ve nedeni üzerinden sayısallaştırı Imıştır. Güvenlik bakış açısında kadın cinayetleri, hızıı toplumsal değişimle yaşanılan yerin ve olumsuz çevre koşullarının bir ürünü olarak ele alınmış ve cinayet suçu, bireyin kültürden bir sapması olarak değerlendirilmiştir (Shaw ve McKay, 1972; Vito ve Holmes, 1994; Snell, 2001; Irmak, 2014). Cinayete uğrayanın cinsiyeti ve belirlenimleri ise dikkate alınmamıştır. Benzer biçimde kadın cinayetleri olgusu 1960 ve 1970'li yıllar boyunca, şiddetin davranışsal boyutu temelinde, sosyal psikolojik kuramlarla açıklanmıştır. Böylece, şiddeti uygulayanın cinsiyeti ve şiddetin öğrenilme deneyimi sorgulanırken, cinslerin rolleri öğrenme ve özdeşleşme ilişkisi temelinde aile içi şiddet olgusu ele alınmıştır. Kadın cinayetleri de, akrabalık ilişkilerinin suistimali ve aile içinde öğrenilen bir davranış döngüsü olarak açıklanmıştır (O'Leary, 1988; Sallan Gül ve Altındal, 2014).

1970’li yıllarda kadın örgütlerinin ve aktivistlerin çabalarıyla kadına yönelik şiddetin bir türü olarak kadın cinayetleri olgusu, feminist bakış açısıyla tartışmaya açılmıştır. 
Feministler, şiddetin erkek egemenliğinin kültürel bir ideolojisi olduğunu; kadınları ikincilleştirdiğini ve kurbanlaştırdığını dile getirmişlerdir (Timisi, 1997; Ağduk, 2005; Dursun, 2008, 2010, 2011; Gencel Bek ve Binark, 2011). Kadınlara karşı şiddetin, eşitsiz toplumsal cinsiyet ilişkilerinin tek nedeni olmasa da en temel mekanizmalardan biri olduğuna dikkat çekmişlerdir (Walby, 1990:142-143; Connell, 1998). Cinsiyet hiyerarşisinin aile başta olmak üzere, tüm toplumsal kurumlarda yapısal, ilişkisel ve sembolik olarak iktidar ilişkileri temelinde yeniden üretildiği belirtilmiş (Kandiyoti, 1988; 1995:369) ve 1970'lerle beraber medyada kadın temsilinin ele alındığı feminist medya çalışmaları başlamıştır.

$\mathrm{Bu}$ çalışmalarda, kadınların toplumsal konumları, ikincilleştirilme dinamikleri ve medyadaki kadın temsilleri toplumsalı yansıtma ve inşa etme süreci bağlamında tartışılmıştır. Kadına yönelik şiddetin kamusal alana çıkışı ise 1980'lerle birlikte başlamış, kadınlar kendi toplumsal konumlarını sorgulama olanağı bulduklarında aile içi şiddet ve kadın cinayetleri olgularını politikanın ve medyanın gündemine taşımışlardır. Toplumsal cinsiyete dair eril söylemin hâkimiyetinin göstergesi olan kadın imgeleri, feminist iletişim ve medya çalışmalarının merkezi ilgi konusu haline gelmiştir (Dursun, 2010:30). Bu çalışmalarda medyanın toplumsalı yansıtmaktan çok, ataerkil cinsiyet rejimini yeniden inşa ederek, güçlendirdiği ifade edilmiştir (Gencel Bek ve Binark, 2000a, 2000b; Çelenk, 2008; Dursun, 2011; 2013; Güncel Bek, 2011; İnci, 2013).

Feminist ve eleştirel medya çalışmalarında temel vurgu, kadın imgesinin cinsellikle ve bedenle eş değer tutularak, cinsiyetçi, ataerkil ve hegemonik değerlerin medya aracılığıyla ve erkek egemen bakış açısıyla yeniden üretildiğine ilişkindir. Medyanın, haber ve yorumlar aracılığıyla toplumsal önyargıları yeniden ürettiği, geleneksel kadın imgesini pekiştirdiği, ya kadını görmezden geldiği ya kadınları az ve eksik yansıttığı ya da onları belirli roller içinde sunduğu belirtilmiştir. Erkek egemen toplumsal kontrolün temel araçlarından biri olarak işlev gördüğüne dikkati çekilen medyanın, farklı kadınlık durumlarını ve yaşamlarını ise eksik temsil ettiğine ya da hiç temsil etmediğine dikkat çekilmiştir. Kadının çoğu zaman ataerkil roller içerisine sıkıştırıldığı, genellikle ev ile bağlantılı olarak gösterildiği, kadının kimliğinin eş ve çocuklarla kurulduğu vurgulanmıştır (Aziz vd., 1994; Saktanber, 1995; Timisi, 1997; Dursun, 2008; KSGM, 2008; Görgün Baran, 2012).

Benzer biçimde, aile içi şiddet haberleri de medyada kadının temsilini ağırlıkla önemsizleştirmekte, olumsuzlamakta, yok sayarak, kurbanlaştırmakta ya da kadını suçlamaktadır (Altun vd., 2007:11; Gökulu ve Hosta, 2013). Dursun'a (2010:23) göre de haber medyası kadına karşı erkek şiddetini normalleştirmekte, kadına ve çocuklara yönelik şiddet ve suistimaller gündemde 'ciddi' haberler arasına bile girmemektedir. Gazioğlu da, kadınlara yönelik cinayetlerin medyada sistematik değil, münferit olduğu kabulünden hareket etmektedir (2013:90). Yazar, kadınların öldürülmelerini toplumsal rollerindeki aksamalara bağlayan cinsiyetçi yaklaşımın söz konusu olduğunu ve şiddeti gerçekleştirenin ve ona maruz kalan cinsiyetin ise görmezden gelinerek cinsiyetçiliğin yeniden üretildiğine işaret etmektedir.

Bu çalışmada da medyada kadın cinayetlerinin temsili ve yer alış biçimleri Radikal gazetesi örneğinde incelenmiştir. İlk olarak kadın cinayeti olgusunun farklı türleri ve kültürel bağlamları ele alındıktan sonra, Türkiye örneğinde kadın cinayetlerinin sosyolojik analizi yapılarak medya bağlamı değerlendirilmiştir. İkinci olarak, gazetede 1 Ocak 2013-31 Aralık 2013 tarihleri arasında yer alan 79 kadın cinayeti haberi analiz edilmiştir. 


\section{Kadın Cinayetini Kavramsallaștırmak, Türkiye’den ve Medyadan Bakmak}

Kadın cinayeti kavramının toplumsal cinsiyet temelli ele alınış, yani kadınların kadın olmaları, toplumların kadınlığa atfettiği rollerin bir sonucu olarak cinayete uğramaları anlamında ele alınışı, 1990'ı yıllarla başlamıştır. Kadın cinayetleri kavramı, kadınların çoğu kez aileleri ya da akraba toplulukları tarafından bireysel ya da topluluk kararıyla öldürülmesini ifade etmektedir. Ülkemizde aileiçi şiddetin kaynağının, topluluğun etik ya da dinsel kurallarının "namus-onur" kavramlarıyla ilişkilendirilmesi nedeniyle kadın cinayetleri kavramı, çoğu kez "namus, töre cinayetleri ya da namus suçları" olarak da adlandırılmaktadır.

Namus, bireyin veya ailenin sosyal onuru veya statüsünü belirleyen şeref kavramının ayrılmaz bir öğesi olarak görülmekte, kadın bedeni ve cinsel davranışa ilişkin gelenek ve göreneklerle ilişkilendirilmektedir. Ataerkil toplumsal değerler sisteminde kadının iffeti, erkeğin namus ve şerefi sayılmaktadır. Kadın cinselliğine aşırı derecede değer atfedilmekte; kadın bedeninin, aile birliğinin, namusun temsilcisi ve koruyucusu olarak erkekler görülmektedir (Illkkaracan ve Arın, 1996; Kardam, 1999; Arın, 2001; Aysan ve Yurdakul, 2006; Işık ve Sakallı-Uğurlu, 2009; Kümbetoğlu, 2010; Aytaç ve Fidan, 2011).

Namus cinayeti, kadının, ailenin namusunu korumak ya da temizlemek için öldürülmesini ifade etmektedir (Yirmibeşoğlu, 1997; Tezcan, 1999; Arın, 2001; Koğacıoğlu, 2004). $\mathrm{Bu}$ anlamda, kadınla özdeşleştirilen ve kadın cinselliğinin kontrol altına alınmasıyla korunmaya çalışılan namus, cinsel saflıkla, bakirelikle eş değer tutulmaktadır (Tezcan, 1999; Parla, 2001; Pervizat vd., 2004; Türkiye'de Namus Cinayetlerinin Dinamikleri, 2005). Bunun anlamı ya da gereği, kadının evlenmeden önce herhangi bir cinsel içerikli davranışta bulunmaması iken, evlendikten sonra da bu tür davranışları sadece kocasıyla yaşamasıdır. Ayrıca, kadının cinselliği sadece cinsel ilişkileri değil; giyiniş ve davranış tarzı, karşı cinsle konuşma, birlikte yürüme, el ele tutuşma, öpüşme ve flört etme gibi çok çeşitli davranışları içerebilmektedir. Kadının geleneksel rol örüntülerini yerine getirmemesi de 'namusunu korumaması' olarak görülebilmekte, sözel ya da fiziksel cezalandırılmasına neden olabilmektedir. Nitekim Türkiye'de evli kadınların \%35'i yaşamlarında en az bir kez kocalarının şiddetine maruz kalmaktadır (Altınay ve Arat, 2009:81-85). Ayrıca bunun da ötesinde pek çok kadın ölüme ya da intihara kadar zorlanmaktadır.

1980'lerde ve 1990'larda kadın hareketinin ve kadın örgütlerinin mücadelesiyle kadına yönelik şiddete bakış değişmeye başlamıştır. Türkiye'nin Kadınlara Karşı Her Türlü Ayrımcılığın Önlenmesi Sözleşmesi'ni (CEDAW) 1985 yılında imzalamasıyla birlikte, kadına karşı şiddetin özel alanın ve kadınların problemi olmadığı, şiddetin bir suç olması nedeniyle istismarcıların cezalandırılması gerektiği düşüncesi resmen kabul edilmiştir. Yine bu sözleşmeyle, medyadaki kadın temsillerinin ayrımcı nitelikte olamayacağı ve bunun önlenmesinin de devletin bir sorumluğu olduğu ilkesi benimsenmiştir (CEDAW, 1992).

1987 yılında "Dayağa Karşı Kadın Dayanışması Yürüyüşü"nden itibaren kadın örgütleri, şiddete karşı mücadelede yasal ve kurumsal değişiklikleri gerçekleştirmek için gerekli kamuoyu baskısını oluşturmuştur. 1990'lı yıllarda ise, şiddetle mücadele sürecinde, kadın danışma merkezleri ile kadın sığınma evleri açılarak kurumsallaşma 
artmış, koruyucu ve önleyici önlemler gündeme gelmiştir (Sallan Gül, 2011; Sallan Gül, 2013). Bu kapsamda, kadın cinayetleriyle ilgili yasal ve kurumsal dinamikler hız kazanmıştır. Özellikle, 1995 sonrasında Pekin Deklarasyonu ve Pekin Eylem Platformu doğrultusunda öncelikli kadın sorunları alanına medya da dâhil edilmiş, (KSGM, 2008) kadın cinayeti olgusu da kültürel bağlamlı olarak gündeme gelmiştir.

Medyada kadının görünümü üzerine yapılan çalışmalar çoğunlukla eleştirel nitelikte olup, feminist bakış açısıyla ele alınmaktadır. Bu süreçte, gündeme bağlı olarak medyanın kadına yönelik şiddet konusundaki rolü, çeşitli program türleri ve haberlerde şiddetin temsil biçim ve stratejileri, şiddet ile kadın arasındaki bağlantıyı yeniden üretme tarzı bağlamında eleştirel medya çözümlemeleri yapılmaktadır.

1995 yılında Kadının Statüsü Genel Müdürlüğü (KSGM) tarafından konuyla ilgili olarak 1996 Yılı Ulusal Eylem Planı için "Kadın ve Medya” bölümü hazırlanmıştır. Bu kapsamda, medya çalışanlarına eğitim verilmesi ile kitle iletişim araçları ve yeni iletişim teknolojilerinde kadınların karar alma sürecine katılımının gerçekleştirilmesi ve bunlara ulaşabilirliklerinin arttırıması ile medyada çağdaş kadın imgelerinin yaygınlaştırılması kararlaştırılmıştır (KSGM, 2008:22). Ayrıca, Türkiye Gazeteciler Federasyonu ile birlikte kadın hakları ve toplumsal cinsiyet eşitliği konularında genç gazetecilere yönelik yarışmalar düzenlenmiş, cinsiyet ayrımcılığına duyarlı televizyon programlarına ödüller verilmiştir. Buna ek olarak, sivil toplum kuruluşlarınca Medya İzleme Grubu-MEDiZ kurulmuştur (KSGM, 2008:24). Diğer yandan da, kadınlara karşı işlenen suçlar yeniden düzenlenirken, Medeni Kanun başta olmak üzere kadınları aile ve toplumda ikincilleştiren kural ve düzenlemelerle mücadele edilmiştir.

1998'de yürürlüğe giren "Ailenin Korunmasına Dair Kanun" aile içi şiddeti suç olarak tanımlamış, şiddet uygulayanın evden uzaklaştırıması gibi özünde kadınları koruyucu önlemlerin yasalaşmasını da sağlamıştır. Ayrıca, 2001 yılında kadın örgütlerinin ve baroların öncülüğünde Kadın Bakış Açısından Türk Ceza Kanunu Reformu Çalışma Grubu oluşturulmuş, yeni Türk Ceza Kanunu çalışmaları başlatılmıştır. Yine 2002 yılında yürürlüğe giren yeni Medeni Kanun'la kamusal alanda olduğu kadar özel alanda da, kadın-erkek eşitliği ilkesi yasaya ruhunu yansıtmıştır. Bu kapsamda, "aile reisliği" ve ona bağlı olarak eşler arası eşitsizlik içeren ikametgâh seçimi, çocuklara ilişkin konularda son söz hakkı gibi hükümleri kaldırılmıştır. Ayrıca, yasal mal rejiminin evlilik içinde edinilen malların boşanma durumunda eşit paylaşımı ilkesi doğrultusunda düzenlenmesi, eşler arası eşitliği temel almış ve kadının ev içi emeğinin değersizleştirilmesini önlemiştir. Yasada "kız/kadın" ayırımı kaldırılmış, "eş" ya da "aile üyesi" olarak gören yasal yaklaşım terk edilmiştir (Demirler ve Gümüş, 2004; Anıl vd., 2005; Şen, 2006). Evlilik içi tecavüz suç olarak düzenlenmiş, namus cinayetlerinde ceza indirimi uygulamalarını engelleyen tedbirler alınmıştır. Töre, ırz, namus, ahlak, ayıp, edebe aykırı davranış gibi ataerkil ve ayırımcı ifadeler de kaldırılmıştır.

26 Eylül 2004 tarihinde TBMM'de kabul edilen yasa, 1 Haziran 2005'te yürürlüğe girmiştir. Türk Ceza Kanunu'nda 2005'te yapılan değişiklikle, cinsel suçların toplumsal düzen ve genel ahlaka karşı suçlar olmaktan çıkarılıp kişiye karşı işlenen suçlar olarak kabul edilmesi de kadınlar açısından çok önemli farklar yaratacak bir bakış açısı değişikliğine işaret etmektedir. Ancak, töre ve namus cinayetlerine meşru zemin hazırlayan hükümlerin kaldırılması 2006 yılına kalmıştır. 18 Mayıs 2005 tarihinde ise TBMM, "Töre ve Namus Cinayetleri ile Kadınlara ve Çocuklara Yönelik Şiddetin 
Sebeplerinin Araştırılarak Alınması Gereken Önlemlerin Belirlenmesi Amacıyla Bir Meclis Araştırması Komisyonu" kurulmasına ilişkin kararı kabul etmiştir.

2006 yılında, 26218 sayılı "Çocuk ve Kadınlara Yönelik Şiddet Hareketleriyle Töre ve Namus Cinayetlerinin Önlenmesi İçin Alınacak Tedbirler” başlıklı Başbakanlık Genelgesi kabul edilerek kadın cinayetlerinde meşru gerekçe gösterilen ataerkil düzenleme ve uygulamaların kaldırılması, bir devlet politikası olarak benimsenmiştir. Bu doğrultuda medyada da dâhil olmak üzere, toplumsal cinsiyet eşitliğini sağlama ve ayrımcılıkları önlenme görevi de KSGM'ye verilmiştir. Bu kapsamda KSGM medyada cinsiyetçi öğeleri araştırarak giderilmesine yönelik önlemleri alacaktır.

Başbakanlık İnsan Hakları Başkanlığı tarafından, Haziran 2008'de açıklanan 'Töre ve Namus Cinayeti Raporu'na göre, 2003-2008 yılları arasında "namus" nedeniyle işlenen cinayetlerin sayısı bini geçmiştir. Raporda kadın cinayetlerinin araştırılması ve bu süreçte medyanın rolünün saptanması için de araştırmaların yapılması kararlaştırılmıştır. Yine kadına yönelik aile içi şiddetle mücadelede ulusal eylem planı hazırlanmıştır. 2007-2010 yılları arasında toplumsal cinsiyet eşitliğinin sağlanması ve kadına yönelik aile içi şiddet konularında toplumsal farkındalık ve zihinsel dönüşümü sağlama hedefinin gerçekleştirilebilmesi için, medya ile işbirliği yapılması esası benimsenmiştir (Demirler ve Gümüş, 2004; Güncel Bek, 2011; Sallan Gül, 2011). Bu kapsamda, medya çalışmaları artmış, medyada kadınların görünümü ve cinsiyetçiliğin saptanmasına yönelik medya etiği konuları tartışmaya açılmıştır.

1990'ların ikinci yarısından itibaren artan medya çalışmalarında ise medyada kadının görünümü araştırılmıştır. Örneğin Timisi (1997:25) yaptığı araştırmalarında, Türkiye'de kadın imgesinin, cinsellikle yani bedenle eş değer tutulduğunu; cinsiyetçi, ataerkil ve hegemonik değerleri kuran ve yeniden üreten, erkek egemen toplumsal kontrolün temel araçları olarak işlev gördüğünü dile getirmiştir. Yine KSGM'nin yaptırdığı çalışmalarda; kadın bedeninin medyada cinselliği çağrıştırdığı, erkeklerin görsel tüketimine sunularak metalaştırıldığı ve ikincilleştirildiği ya da sadece ev içinde ailenin bir temsilcisi olarak sunulduğu ve ataerkil yapının etkilerini daha da pekiştirdiği ortaya konulmuştur. Dolayısıyla, medyanın kadınları öncelikle "bedene" indirgediği, farklı kadınlık durumlarını ve yaşamlarını temsil etmediği, kadınların çoğu zaman ataerkil roller içerisine sıkıştırdığı, genellikle ev ile bağlantılı olarak gösterdiği belirtilmiştir. Böylece, medyanın haber ve yorumlar aracılığıyla, toplumsal ön yargıları ve cinsiyetçi söylemi yeniden ürettiğine dikkat çekilmiştir.

\section{Radikal Gazetesinde Kadın Cinayetlerinin Toplumsal Cinsiyet Bağlamı Cinsiyetçiliği Dönüștürüyor Mu? Yoksa Yeniden Üretiyor Mu?}

\section{1.Çalıșmanın Metodolojisi}

Bu çalışma, medyada cinsiyetçiliğin yer alış biçimlerini Radikal gazetesi örneğinde ele almaktadır. Radikal Gazetesi yayın ilkeleri bakımından kadınlar lehine yayıncılık yaptığını belirten ve kadına karşı şiddetle mücadeleyi benimsediğine vurgu yapan bir gazetedir $^{3}$. Bu nedenle, kadına karşı şiddetle mücadeleye duyarlı olduğunu öne süren

3 Radikal gazetesinde 11/12/2012 tarihli Serkan Ocak'ın "Doğan Yayın Holding, 13 yıllık 'Yayın İlkeleri'ni günün intiyaçlarına göre geliştirerek yeniledi. Yayın ilkeleri arasına sosyal medya da girdi.", başlıklı haberinin "Kadın- 
bir gazete olan Radikal gazetesinde kadın cinayeti haberlerinin veriliş biçimini ele alan bu çalışma, Mart-Nisan 2014 tarihlerinde gerçekleştirilmiştir. Gazetenin Batı Akdeniz Bölgesi Antalya Hürriyet Haber Ajansı temsilciliğinde araştırmalar yürütülmüş, Radikal gazetesinin 1 Ocak 2013-31 Aralık 2013 tarihleri arasında yayınlanmış olan 79 adet aileiçi şiddet bağlamlı kadın cinayeti haberi ${ }^{4}$ araştırmacılar tarafından incelenmiştir.

Kadın cinayeti haberlerinin haber değeri taşıma niteliği sorgulanmış, haberlerin içerik analizi kategoriler oluşturularak nitel ve eleştirel medya çözümlemesi yapılmıştır. Kadın cinayeti haberlerinin haber olma niteliği medyada kadın haberlerinin yer alış biçimlerinde ele alınan iki değişken etrafında; haberin yayın sayfası ve sayfada yer alış biçimi üzerinden cinsiyet temelli (gendered) söylem analizi yapılmıştır. Ayrıca, haber başlıklarında ve metin içeriklerinde kullanılan kavram ve anlatılar üzerinden de toplumsal cinsiyet analizi yapıımıștır. Bu doğrultuda; haberin kimin tarafından yazıldığı, kaynağı, yazarın bakış açısı, kadın cinayetini ve ölümü niteleyen kavram seti ile failin ve mağdurun tanımlanış biçimleri üzerinden ana kategoriler belirlenmiş, sayısal veriler de grafiklerle sunulmuştur.

\subsection{Kadın Cinayeti Haberlerinin Haber Değeri Tașıma Niteliği}

Medyada kadın haberlerinin yer alma biçimlerini inceleyen çalışmalarda çoğunlukla konunun haber olma değeri; haberin sayfası, yayınlanma yeri ve sayfada ne kadar yer tuttuğu gibi öğelerle belirlenmektedir. Kadın yönelik şiddet haberleri üzerine yapılan çalışmalarda genellikle kadınlara ilişkin haberlerin ön ve arka kapak gibi dikkat çekici yerlerde yer almadığı, daha çok iç sayfalarda magazin haberleri arasında kısa anlatılara yer verildiği belirtilmektedir (Timisi, 1997; Dursun, 2010; Güncel Bek ve Binark, 2010). Örneğin, KSGM'nin (2008) 2007 yılında yaptırdığı medya araştırmasına göre, yazılı basında aile içi şiddet haberlerinin sadece \%9,1'i gazetelerin birinci sayfasında yer alırken, bu tür haberlerin büyük bir kısmı 3. sayfada yayınlanmıştır. Yine Gencel Bek ve Binark da (2011:10), yazılı basında kadına yönelik şiddet haberleri üzerine yaptıkları çalışmada bu tür haberlerin gazetelerin üçüncü sayfalarında yoğunlaştığı ifade edilmektedir. Benzer olarak Birleşmiş Milletler Nüfus Fonu'nun (UNFPA) teknik desteğiyle KSGM tarafından Kadına Yönelik Aile İçi Şiddetle Mücadele Projesi kapsamında başlatılan araştırmada, dört günlük gazetenin (Posta, Hürriyet, Zaman ve Sabah), Eylül 2006-2007 tarihleri arasında yayınlanan 1.400 haberi incelenmiştir. Yine ilgili gazetelerin editörleriyle görüşmeler yapılmıştır. Bu araştırmada, şiddettin ölümle sonuçlanması halinde haber değeri taşıdığı görüşü öne çıkmıştır. Bir başka ifadeyle, kadına yönelik şiddet ancak 'ölümle sonuçlanırsa' haber olarak medyada yer almaktadır (Altun vd., 2007:53).

Bu çalışma kapsamında ele alınan Radikal gazetesinde, 2013 yılında yayınlanan kadın cinayeti haberlerinin haber değeri; haberin sayfası, habere ne kadar yer verildiği ya da sayfada kapladığı yer bakımından değerlendirilmiştir. 2013 yılında işlenmiş olan kadın cinayetlerinin ancak dörtte biri, yani 79 kadın cinayeti haberi, Radikal gazetesinin farklı sayfalarında yer bulmuştur.

çocuk haklarında taraf” alt başlığında konu şöyle ifade edilmektedir; “ ...Gazete ve dergi çalışanları, kadın ve çocuk hakları konusunda taraftır. Kadına ve çocuğa karşı ayrımcılığa neden olacak, ruhsal ve bedensel açıdan örseleyecek veya rencide edecek haberlere yer verilmez. Kadına ve çocuğa karşı şiddeti önlemeyi amaçlayan yayınlar yapılır...", http://www.radikal.com.tr/turkiye/dogan_yayindan_yeni_ilkeler-1111490; serkan.ocak@ radikal.com.tr/arşiv), erişim tarihi 10.02.2013.

4 Kadın cinayeti kapsamına giren ama nefret cinayeti içerikli 3 haber bu çalışmaya dâhil edilmemiştir. 


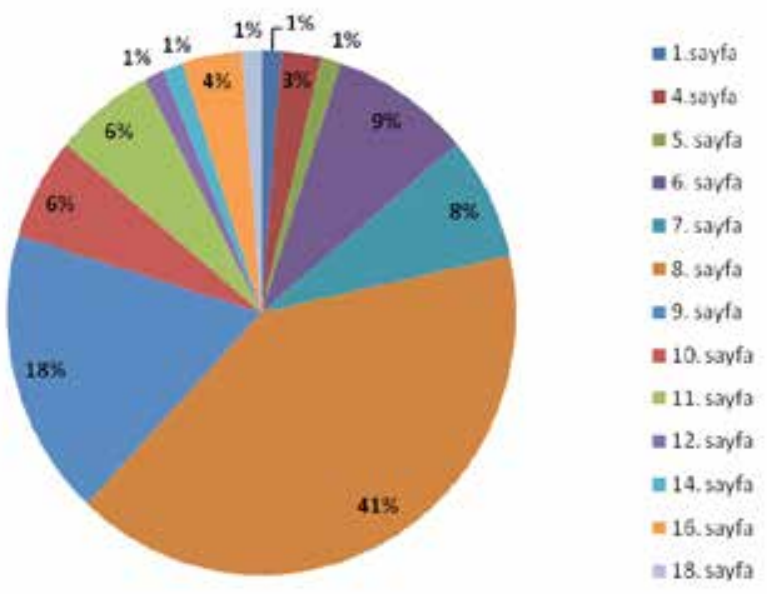

Şekil 1: Kadın Cinayeti Haberlerinin Yer Aldığı Sayfa

Şekil 1'de görüldüğü gibi kadın cinayeti haberlerinin \%59'u gazetenin 8 . ve 9. sayfalarında yer almıştır. Sadece bir haber 1. sayfada kendine yer bulurken, ağırlıkla iç ve arka sayfalarda ilgili haberler yayınlanmıştır. Benzer biçimde, kadın cinayeti haberlerinin neredeyse üçte ikisi (\%66'sı) sadece bir paragraflık bir bilgi ile okuyucuya sunulmuştur. Kadın cinayetine ilişkin haberlerin, haberin sayfası ve sayfada kapladığı yer bakımından ciddi haberler sıralamasına giremediği görülmektedir. Bu haberler daha çok magazin değeri olan haber grubunda yer almaktadır. Şiddet medyada daha dar bir çerçevede, fiziksel şiddet boyutuyla ele alınmakta, şiddetin yoğunluğu ve stratejileri üzerinde durulmaktadır (Dursun, 2010:20-21). Radikal gazetesinde de kadın cinayetinin nedeninin verildiği haberlerde bu bakış açısı yansıtılmaktadır. Kadınların ölüm biçimlerine ve kullanılan araçlara ilişkin detaylarla haber sansasyonel hale getirilerek ölümün ızdırap verici halleri okuyucuyla paylaşılmıştır.

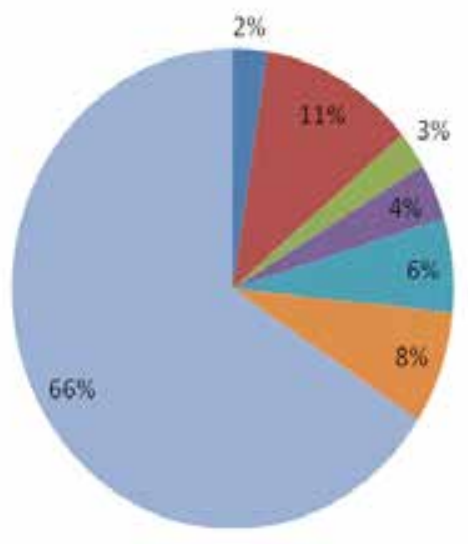

- Tam Sayfa

- Yanm Sayfa

- 5 Paragraf

- 4 Paragrá

e 3 Paragraf

a 2 Paragraf

in 1 Paragraf

Şekil 2: Kadın Cinayeti Haberlerinin Sayfada Kapladığı Yer 
Kadın cinayetine ilişkin haberlerin ancak dörtte birinde olay hakkında detaylı bilgiye yer verilmektedir. Çoğu haber ise polis kayıtlarından alınan bir ya da birkaç paragraflık adli nitelikli bilgi olarak aktarılmaktadır.

Radikal gazetesinde yer alan haber başlıkları ve içeriklerinde kadınların öldürülme nedeni haberlerin dörtte üçünde okuyucuya iletilmemektedir. Dörtte birlik bölümünde öldürme silahı olarak ateşli silahlar ve bıçak olduğu bilgisine yer verilmektedir. Kadınların öldürülme biçimlerinin acı çekilerek (vurulma ve bıçaklamayla) gerçekleşmesi, kadına yönelik şiddetin ve kadın cinayetlerinin vahşetini normalleştirmektedir. Ayrıca haberler eril bir bakış açısını yansıttığı için, kadınlara cinsiyet rollerine ilişkin öğüt verici mesaj içeriği taşımaktadır. Kendilerinden beklenilen "geleneksel eş ve akrabalık rolü" ile davranışlarını sergilememeleri durumunda ise, yaşamlarının nasıl sonlanabileceği bu mesajlar aracılığıyla iletilmektedir. Örneğin, 5 Ocak 2013 tarihli "Boşanmak istedi, öldürüldü!" başlıklı haberde kocanın kadını öldürdükten sonra akrabalarına da "... Kızınızı öldürdüm sizi de öldüreceğim..." diye tehditte bulunduğu gibi ifadelerle, erkek şiddeti yeniden üretilirken, diğer kadınlara gözdağı mesajı da yayılmaktadır.
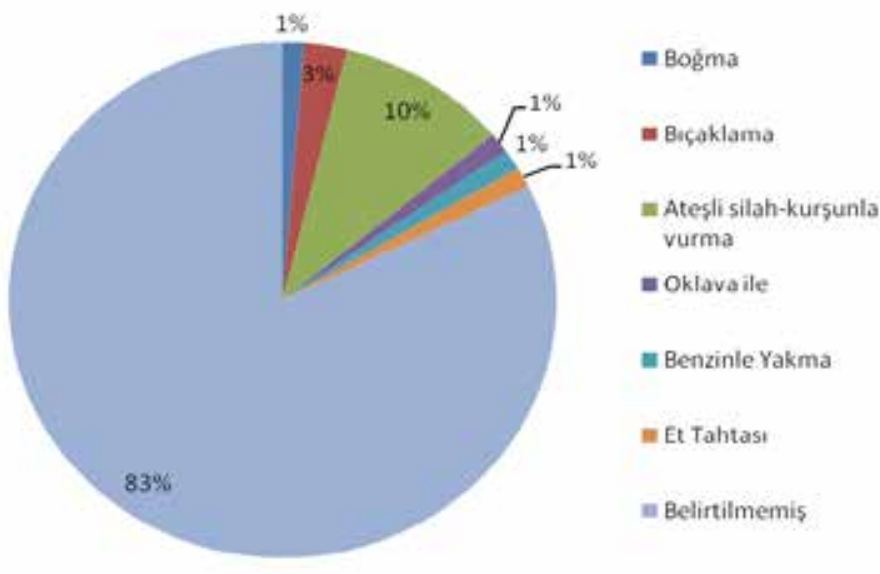

볼 Benzinle Yakma

Et Tahtast

E Belirtilmemis

Şekil 3: Kadınların Öldürülmesinde Kullanılan Araçlar ve Yöntemler

\subsection{Kadın Cinayeti Haberlerinde Cinsiyetçiliğin Yeniden Üretim Biçimleri}

Kadın cinayeti haberlerinde kullanılan dilin niteliği ve söylemin üreticisinin cinsiyeti, toplumsal cinsiyet analizi açısından oldukça önemlidir. Bu analiz, aynı zamanda haberin hangi bakış açısıyla yazıldığını da belirlemektedir. Radikal gazetesinde yer alan 79 haberin sadece 3'ü kadın yazarlar ${ }^{5}$ tarafından, kadın bakış açısıyla yazıımıştır. Medyada kadın muhabir ve yazar sayısının azlığı bu yayın organı için de söz konusudur. Kadın cinayeti haberleri kaleme alınırken erkek yazarların, kadın yazarlarla kıyaslandığında eril bakışı daha fazla benimsemiş oldukları söylenebilir. 


\subsubsection{Kadın Cinayeti Haberlerinin Sıradanlaștırılması}

Kadın cinayeti haberlerinin neredeyse tamamının yazarı ve haber kaynakları da çoğunlukla erkeklerden oluşmaktadır. Haberlerin içeriğinde kullanılan görsellerde ve ifadelerde olaya ilişkin bilginin ya yakın komşulardan ya da yakın çevredeki erkeklerden alındığı görülmektedir. Benzer biçimde, adli vakalarda da özellikle erkek polislerin raporlaştırdığı bilgilerden yararlanılmaktadır (Sallan Gül ve Altındal, 2014). Aslında, olayların haberleştirilmesinde basın organlarının tarafsız ve özgün olması gerekir (Dursun, 2010:26-27). Ancak, kadın haberleri söz konusu olduğunda basının bu işlevini tam olarak yerine getirdiği çok da söylenememektedir. Bu çalışmada, Radikal gazetesindeki kadın cinayeti haberlerinin başlıklarının üçte ikisinde, erkeklerin ölüm eylemini meşrulaştırıcı, erkeklik rol, beklenti ve davranışlarını haklılaştırıcı ya da ölümü mazur gösterici başlık ve kavramlar kullanıldığı belirlenmiştir. Örneğin, "Eşini ÖIdürüp İntihar Etmiş" (1 Ocak 2013), "Töre İçin Çifte Cinayeti Üstlenmiş" (16 Şubat 2013), "Bir Aile Sırlarıyla Yok Oldu” (16 Ocak 2013), "Polis'in 'Mehtap' Yanıtı: Fazla Arka Sokaklar İliyorsunuz" (22 Ocak 2013) gibi başlıklarda olduğu gibi.

Benzer biçimde, kadın cinayeti haberlerindeki cinsiyetçileştirmedeki bir başka boyut, haber içeriklerinde toplumsal cinsiyet duyarlıı̆̆ını arttırıcı ve toplumsal cinsiyet eşitlikçi bir söylem kullanmanın, şiddete karşı koruyucu önlemleri gündeme getirmenin ve yasal süreçlerle ilgili bilgilendirme yapma düzeyinin yetersiz olmasıdır. Aslında, toplumda dezavantajlı konumda olan kişilerin, özellikle kadınların, haklarını korumak ve bilgilendirmek medyanın görevleri arasındadır (Timisi, 1997; Dursun, 2010, Güncel Bek, 2011). Bu anlamda, kadın cinayeti haberlerinde yasal süreç ve dinamikler hakkında bilgilendirme yapılması okuyucunun ve mağdurun korunması bakımından da oldukça önemlidir. Bu anlamda, Radikal gazetesinde yer alan kadın cinayeti haber başlıklarında hukuksal bilgiye çok az (\%1) yer verilirken, metinlerde daha fazla açıklama (\%24) yapılmaktadır.

\subsubsection{Kadın Cinayeti Haberlerinin Kavramsallaștırılması}

Kadın cinayeti haberlerinin başlıkları, ölüm haberinin duyurulduğu kavramlar temelinde ele alındığında, haber başlıklarının yarısına yakınında (\%46'sında) kadınların nasıl öldürüldüğüne ilişkin bilgi verilmemektedir. Ancak, gazetenin haber başlıklarında ölüme ilişkin kavramların \%49'unda failin eylemine, yani 'öldürmesine' ve nasıl öldürdüğüne vurgu yapılmaktadır.

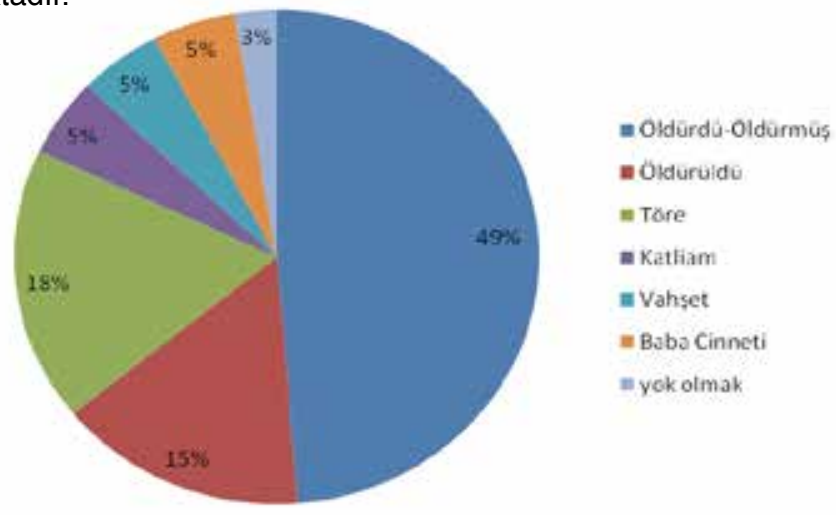

Şekil 4: Kadın Cinayeti Haber Başlıklarında Ölümü Niteleyen Kavramlar 
İkinci sırada haber başlıklarının \%18'inde töre kavramına yer verilmektedir. Ancak, töre kavramıyla verilen başlıklarda ve haber metinlerinde ikili bir tutum izlenmektedir. Bir yandan törenin hem kadınları, hem de erkekleri nasıl etkilediği anlatılmakta, öte yandan her iki cins de kurbanlaştırılmaktadır. Böylelikle, bu metinlerde gerek ölme ve gerekse öldürme eylemlerinin kaçınılmazlığına vurgu yapılmaktadır. Benzer biçimde, haber başlıklarının \%15'inde de kadın cinayetleri ‘öldürüldü' kavramı başlığı ile birlikte duyurulmaktadır. Dolayısıyla, cinayete kurban edilen kadınların, ölüm karşısında pasifliğine ve çaresizliğine dikkat çekilmektedir.

\subsubsection{Kadın Cinayetlerinin Cinsiyetçileștirilmesi}

Kadın cinayeti haberlerinin hem başlıkları, hem de metin içerikleri incelendiğinde cinayetlerin nedenlerinin nasıl ifade edildiği bakış açısının belirlenmesi bakımından oldukça önem kazanmaktadır. Radikal gazetesi örneğindeki haber başlıklarında kadın cinayetlerinin nedenlerine bakıldığında, haber başlıklarının \%89 gibi büyük çoğunluğunda herhangi bir neden belirtilmediği, daha çok olayın sürecine ya da sonucuna odaklanıldığı görülmektedir.

Kadın cinayetlerinin nedenleri incelendiğinde, haber başlıklarının sadece \%11'inde nedenlerin belirtildiği görülmektedir. Kadının boşanma isteği ile ev içi geleneksel rollerine itiraz etmesi (yemek yapmamak gibi) ya da 'aykırı' davranış ve taleplerde bulunması gibi nedenler, öldürülmelerine yol açmaktadır. Öldürülme eyleminin de, bu anlamda 'töre adına' gerçekleştirildiği ifade edilmektedir. Örneğin; "Dilan'ı Öldüren Kanal Değil Töre" (24 Ocak 2013 tarihli haber), "Gülşah Öğretmene Vahşetin İtirafı" (16 Ocak 2013 tarihli haber) gibi başlıklarla kadınların ölümlerinin kadın olmalarından ve töreden kaynaklandığına ilişkin bilgi verilmektedir.

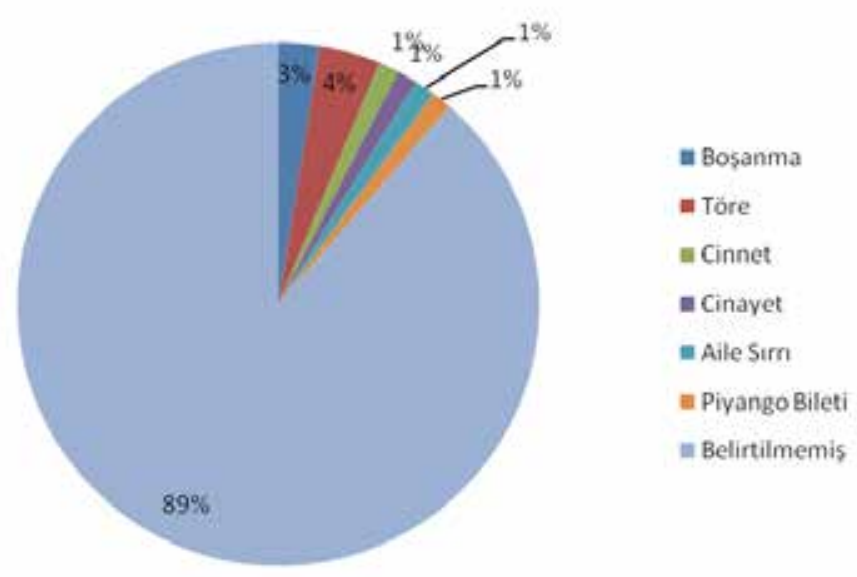

Şekil 5: Kadın Cinayeti Haber Başlıklarında Ölümlerin Nedenleri

Haber başlıklarındaki bakış açısı ele alındığında, yazıların \%39'unda doğrudan eril bir dil kullanılmaktadır. Haberlerin başlıklarında erkeğin eylemini, yani kadını öldürmesini meşrulaştıran bir bakış açısı yansıtılmıştır. Örneğin; "Töre İçin Çifte Cinayeti 
Üstlenmiş" (16 Şubat 2013 tarihli haber) başlıklı haberde, öldüren kişinin (babanın) cinnet geçirmesi, erkeğin davranışını, öldürme fiilini mazur gösteren bir mazeret gibi sunulmaktadır.

Haber metinlerinde kadınların ölümü 'hak ettiği' doğrudan yazılmasa da, "kadınlık ve erkeklik" rol örüntü ve beklentileriyle ifade edilerek gizil/örtük mesajlarla verilmektedir. Bununla birlikte, haberlerde erkekler tarafından işlenen kadın cinayetlerinin eril meşrulaştırma ile sunulduğu anlaşılmaktadır. Örneğin; 7 Kasım 2013 tarihli "9 Aylık Hamile Dövülerek Öldürülmüş" başlıklı haberde cinayetin nedeni, kadının evde olan kayınbiraderine '...hasta ve hamile olduğu için yemek hazırlayamaması...' olarak ifade edilmektedir. Yine 13 Ekim 2013 tarihli "Gelinlik Cinayeti” başlıklı haberde, düğün hazırlığındaki nişanlı çiftin, yani kadının gelinliği beğenmemesinin öldürülmesine yol açtığı haberleştirilmektedir.

Bu ve benzeri örnekler kadınlardan beklenen itaatkâr, uysal, pasif ve fedakâr kadın rolünün yerine getirilmemesinin ve Türkiye'deki kültürel ve geleneksel kadın rol modeline uyulmamasının, kadınlar için bir öldürülme nedeni olduğu yargısını güçlendirmektedir. Benzer biçimde Radikal gazetesindeki çok sayıdaki yazıda, erkeğin işsizliği ve yoksulluğu gibi durumlar, onun ev içindeki üst konumunu ve otoritesini zedeleyen ve aile içi şiddeti ve kadın cinayetlerini meşrulaştıran bir söylem çerçevesinde sunulmaktadır. Yine örtük cinsiyetçi anlatılarla erkeğin psikolojik dengesinin bozulması ve cinnet geçirmesi gibi geleneksel açıklama modelleri ve ataerkil savunma mekanizmalarıyla erkekler, adeta 'suçsuz ve zan altında bırakılmış bireyler' olarak ilan edilmeye çalışılmaktadır. Örneğin, 13 Ağustos 2013 tarihli "Zor Yürüyor, Eşini Öldürdü" başlıklı haberde, failin eşini evde, tartışma sonrasında öldürdüğü belirtilmektedir. Haberin kaynağı olan komşuların ifadelerinde, failin eşini öldürme nedeni olarak 'akıl sağlığı' problemine dikkat çekilmekte, 'bilinç kaybı' ifadesiyle cinayet açıklanmaktadır. Benzer biçimde Radikal gazetesinin 19 Eylül 2013 tarihli "Baba Cinneti 4 Can Aldı" başlıklı haberinde, failin 'cinneti geçirdiği' belirtilmekte, cinayetin nedeni psikolojik soruna indirgenmektedir (Sallan Gül ve Altındal, 2014:215).

\subsubsection{Kadın Cinayeti Haberlerinde Failin Yer Alıș Biçimleri}

Kadın cinayeti haberlerinde faillerin akrabalık kimlikleri öne çıkartılmakta ve eril bakış iki türlü yansıtılmaktadır. Bunların ilkinde, failin akrabalık statüsüne hem haber başığında, hem de içerikte yer verilerek aile içi cinsiyet rolüne dikkat çekilmektedir. 79 haberde cinayet failinin \%44'ünün eş ve eski eş, \%17'sinin de nişanlı ya da eski nişanlısı, yani faillerin \%61'inin kadının en yakınındaki erkekler olduğu bilgisi verilmektedir. 

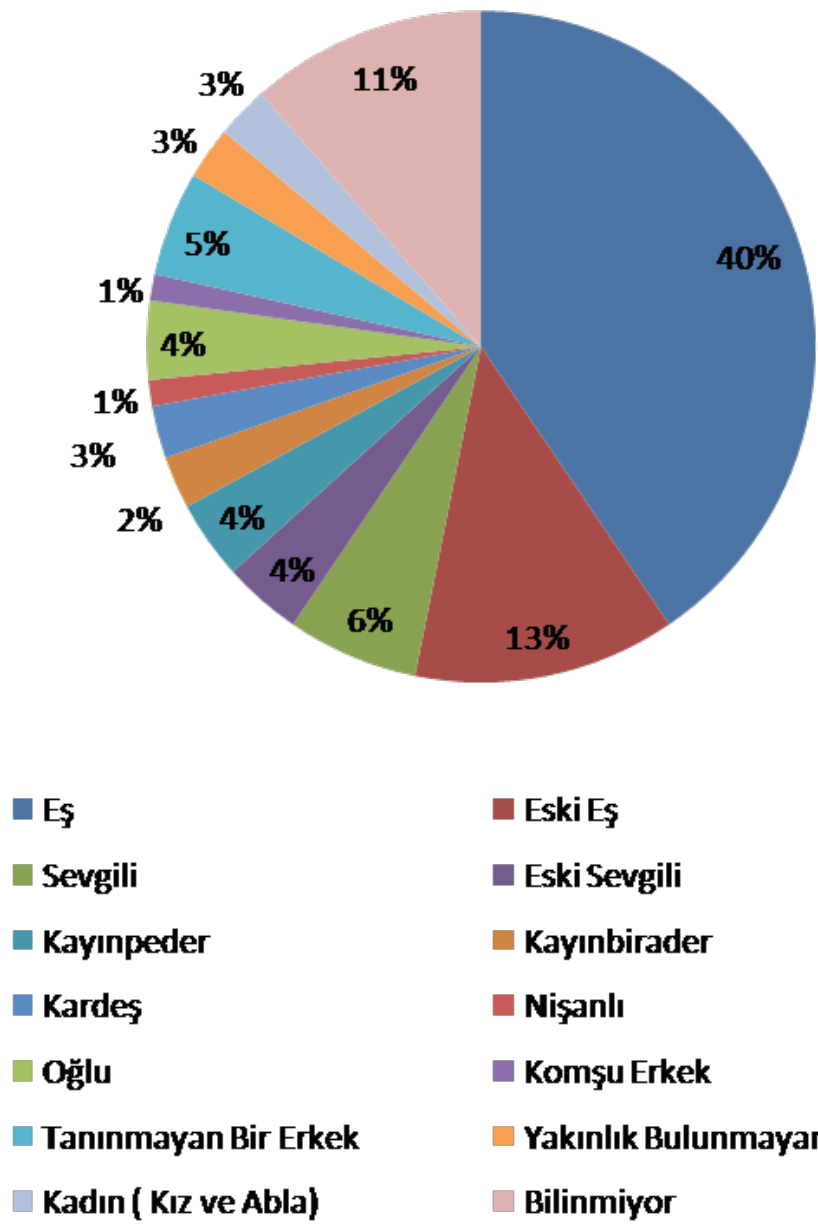

Eski Es

Eski Sevgili

Kayınbirader

- Nişanlı

Komşu Erkek

Yakınlık Bulunmayan Bir Erkek

Bilinmiyor

Şekil 6: Kadın Cinayetlerinde Failin Maktulle Yakınlığı

Ancak failleri tanımlayıc bilgiler, meslekleri ya da diğer toplumsal rol ve kimlikleri göz ardı edilmektedir. İkincisinde ise failin cinayeti neden işlediği bilgisine çok az yer verilmektedir. Olayın nedenleri ortaya konmadan münferit bir olaymış gibi sunulurken, haberlerde failin eylemini nasıl yaptığı, öldürdüğü gibi öğeler abartılarak verilmektedir. Bir başka ifadeyle, kadın cinayetlerinde erkeklerin; 'koca, eski koca ya da koca adayı' olarak görevleri, dar bir eril kalıp içinde tanımlanarak cinayetin nedenlerinin önemsiz gibi sunulması cinsiyetçiliği yeniden üretmektedir. Yine, fail erkeklerin haber başlıklarında nasıl tanımlandıklarına bakıldığında, bilgi verilmeyerek failin korunduğu görülmektedir. 


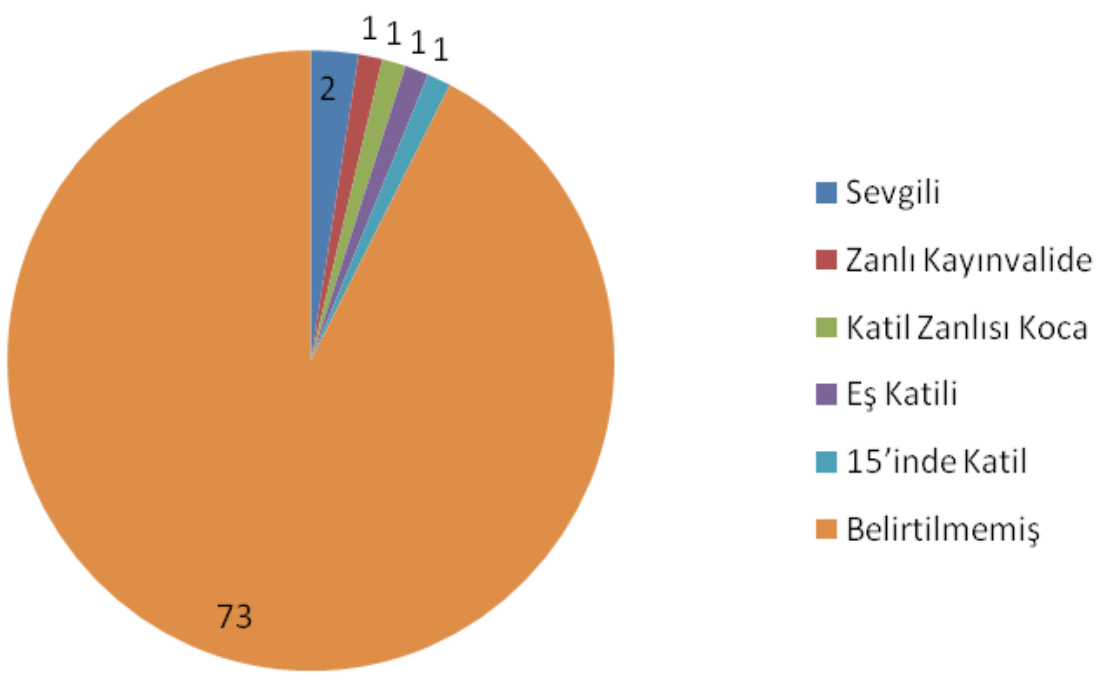

Şekil 7: Haber Başlıklarında Failin Tanımlanması

\subsubsection{Kadının İkincilleștirilmesi ve ölümü}

Kadın cinayeti haberlerinde öldürülen kadının aile içi ve toplumsal statüsü ise ikilemli bir rol dizgesiyle anlatılmaktadır. Bu haberlerde ya kadınların anne olma statüsü öne çıkarılmaktadır. 'Hamile Eşine Kurşun Yağdırdı' (30 Nisan 2013) ve 'Íki Hamile Kadın Bebekleriyle Öldü' (17 Nisan 2013) haberlerinde olduğu ya da 'Esin Öğretmenin Eşine Müebbet' (14 Mart 2013) ve 'Özlem Hemşire De Kurtarılamadı'(24 Ağustos 2013) başlıklı haberlerde olduğu gibi, öldürülen kadınların kamusal alanda isimlerine ve mesleki statülerine yer verilmektedir. Ancak, kamusal saygınlığına karşın ev içi rolleri nedeniyle madun olan kadın, kendine düşen rolü oynamayı reddederse ya da modern kamusal rollerinin bireyleştirici talepleriyle özgürlüğünü isterse sonunun ölüm olduğu mesajı metin içeriklerinde sıklıkla tekrar edilmektedir.

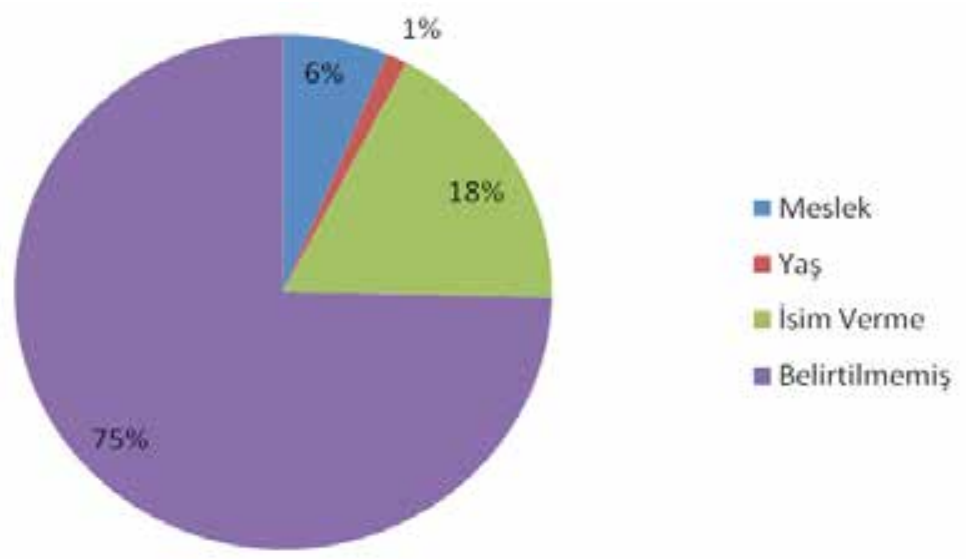

Şekil 8: Cinayete Uğrayan Kadınların Haber Başlıklarında Belirtilen Nitelikleri 
Haberlerde, özellikle kadınların eğitimli olmalarına ve kamusal alanda saygınlık gören statülerine yer verilse dahi bu statünün, anne olmanın önüne geçmesi durumunda kadının öldürülebileceği iletisi vurgulanmaktadır. Örneğin, 16 Ocak 2013 tarihli "Gülşah Öğretmene Vahşetin İtirafı" başlıklı haber ile 17 Aralık 2013 tarihli "Koruma Kararının Bittiği Gün Öldürüldü" haberlerinde olduğu gibi. Öldürülen kadınların öğretmen ve öğretim görevlisi gibi meslekleri olsa da kadınlık rollerini yeterince iyi yapmamaları ya da bu rollere itiraz etmeleri durumunda ölümden kaçamadıkları/kaçamayacakları mesajı verilmektedir.

\section{Sonuç}

Ataerkil toplumsal değerler sisteminde kadına, onun bedenine, cinselliğine ve doğurganlığına yüklenen aşırı önem, namusla ve özel alanla, yani aile ve kadının aile içi rolleriyle tanımlanmaktadır. Hatta kadının cinselliği, bedenin eş dışında tüm erkeklerden korunmasının yanı sıra, özel ve kamusal alanda kabul gören kadınlık ve annelik rolüne indirgenmektedir. Kadının geleneksel rol örüntülerini yerine getirmemesi ve/veya 'namusunu korumaması' durumunda ise, sözel ya da fiziksel olarak cezalandırılması normalleştirilmekte ve meşrulaştırılmaktadır. Bir başka ifadeyle, ailenin ve namusun kadınla ve kadın bedeniyle somutlaştırıldığı ve onun da şiddet içeren yöntemler dahi kullanılarak korunması ve denetlenmesi gerektiğine dayanan ataerkil anlayış, bu "görev"i adeta erkeklere vermektedir.

Ailede kadını güçsüzleştiren, erkeğe otorite ve kontrol rolü yükleyen ataerkil yapı ve değerler, kadın ölümlerini meşrulaştırıcı bir ahlaki ve toplumsal zemin yaratmaktadır. Özellikle, kadın ve erkek arasındaki rol ve davranışsal farklılıklar, bir zıtlık olarak tasarlanmakta, bu bağlamda insani ilişkiler de güç ilişkileri temelinde tanımlanmaktadır. Şiddetin temsili ise erkeğin kadından daha güçlü olduğunu öne süren 'biyolojik farklılıklar' söylemine dayanmaktadır. Dolayısıyla, kadınları doğaları gereği itaatkâr, pasif, bağımlı ve güçsüz olarak gören bu anlayış erkekleri saldırgan, etkin ve güçlü olarak resmetmektedir. Medyanın da inşasında rol oynadığı bu tabloda, kadın ve erkek arasındaki farklılık üzerinden bu söylem temel alınarak iletilmektedir.

Kadını ve erkeği eşit görmeyen, rol hiyerarşisi temelinde kadını ikincilleştiren bakış açısı cinsiyetçi ve ataerkildir. Bu cinsiyetler hiyerarşisi, ailede oluşturulmakta ve diğer toplumsal kurumlar ve medya aracılığıyla yeniden üretilmektedir. Bu anlayış, 1970'li yıllarla birlikte kadın örgütlerinin çabalarıyla değişmeye başlamıştır. Bu doğrultuda, medyada da kadına yönelik şiddetin en ağır biçimi olan, kadınların kadın olmaları nedeniyle öldürülmelerini ifade eden kadın cinayeti olgusu, faillerin büyük çoğunlukla akraba erkeklerden olmasının, ailedeki geleneksel rolleri, bunları üreten, sürdüren, pekiştiren süreçlerin ve mekanizmaların sorgulanmaya açılması konularını da beraberinde getirmiştir.

Feminist medya çalışmaları aracılığıyla medyada kadın temsili sorunsalı farklı boyutlarıyla gündeme gelmiştir. Medyada şiddeti ve özelde de kadına yönelik şiddeti sıradanlaştırma, önemsizleştirme, normalleştirme, magazinleştirmeve cinsiyetçileştirme süreçleri, erkeğin gerçekliğinin, kadının gerçekliği haline dönüştürülme dinamikleriyle (Lundgren, 2009:20) tartışılmaya başlanmıştır. Bu çalışmada da medyada kadın temsili sorunsalı kadın cinayetlerine ilişkin haberler temelinde Radikal gazetesi örneğinde değerlendirilmiştir. Gazetenin isminin radikal ve sorgulayıcı niteliği olmasına karşın, 
kadın cinayetlerine yönelik bakış açısında çelişkili tutum izlediği, toplumsal cinsiyet eşitliğine dönük duyarlılık sağlama ve bilgilendirme işlevini yerine getirmede yetersiz kaldığı görülmektedir. Radikal gazetesinin yayın ilkelerinde eşitlikçi, hatta kadınlar lehine yayın politikası benimsendiği vurgusuna karşın, gazetenin kadın cinayetleri olgusuna yeterince duyarlı yaklaştığını söylemek güçtür. Radikal gazetesinde kadın cinayeti konusu aslında 'ciddi' haberler sıralamasına bile girememekte, haberlerin çoğu haber kaynağı ve haberin veriliş biçimi bakımından resmi kurumların eril söylemini aktararak, cinsiyetçiliği yeniden üretmektedir. Çoğu haberde doğrudan olmasa bile, haber başlıklarında ve kavramsallaştırmalarda gizil cinsiyetçilik sergilenmektedir. Özellikle, haberlerin alt metinlerinde geleneksel-modern kadın çatışması kadınlık rolleri temelinde kadınlara gözdağı veren iletilerle sunulmaktadır.

Kadın cinayetlerinin nedenlerine ilişkin bilgilere gazetede çoğunlukla yer verilmemektedir. Verilenlerin de, geleneksel kadın rolleri etrafında tanımlanan bir 'namus' söyleminin içeriği, geleneksel ve modern kadın rolleri arasındaki çatışmaya odaklanılarak ele alınmaktadır. Kadınların kendi yaşamları hakkında söz sahibi olması, ekonomik bağımsızlığını kazanması, boşanmayı istemek gibi 'modern kadın olma' davranış kodlarının, onları ölüme götüren nedenler olarak eril bakış acısıyla çoğu kez gizil mesajlarla sunulması söz konusudur.

Bu bulgular, yazılı medyanın en azından Radikal gazetesi örneğinde, eşitlikçi bir toplumun inşasında toplumsal sorunlara yeterli düzeyde toplumsal cinsiyet duyarlılığıyla yaklaşmadığını göstermektedir. Oysa, medyanın toplumsal cinsiyet eşitliğinin sağlanmasına ve kadınlara yönelik şiddet dâhil tüm ayrımcılıkların önlenmesine yönelik etik ve sosyal sorumluluğu olduğu unutulmalıdır. Bu kapsamda, medyanın eril dili nasıl ürettiği kadar, nasıl dönüştürmesi gerektiğine ilişkin çalışma ve politikalar da geliştirilmelidir.

\section{Kaynakça}

Ağduk, Meltem (2005). Harika Ne Bu Hal! Medya Kadınlar ve Şiddet, http://www.huksam. hacettepe.edu.tr/Turkce/SayfaDosya/harika_bu_ne_hal.pdf., ss. 1-7. Erişim tarihi: 21.10.2014

Altun, Abdulrezak, Gencel Bek, Mine \& Altun, Esen (2007). "Aile İçi Şiddet Haberlerinin Üretim Süreci ve Medya Profesyonelleri. ” İletişim Araştırmaları Dergisi. 5(2):9-61.

Anıl, Ela, Arın, Canan, Berktay Hacımirzaoğlu Ayşe, Bingöllü Mehveş, illkkaracan Pınar \& Ercevik, Amado (2005). Turkish Civil And Penal Code Reforms From A Gender Perspective: The Success Of Two Nationwide Campaigns, İstanbul. www.kadininisanhaklari.Org.

Erişim Tarihi: 18.10 .2014

Arın, Canan (2001). "Femicide in The Name of Honor in Turkey. "Violence Against Women. 7: 821-825.

Aysan, Sev'er \& Yurdakul, Gökçeçiçek (2006). "Culture of Honor, Culture of Change: A Feminist Analysis of Honor Killings in Rural Turkey." içinde Beyond Borders: Thinking Critically About Global Issues, (Ed.) P. Rothenberg, New York, NY: Worth Publishers, ss. 288-295.

Aytaç, Serpil \& Fidan, Fatma (2011). Kadın Cinayetleri: Sevgi Mi, Namus Mu? Suç Önleme 
Sempozyumu, Bursa, ss. 168-184.

Altınay, Ayşe Gül \& Arat, Yeşim (2009) Violence against Women in Turkey: A Nationwide Survey. Ponto Publications: İstanbul.

Birleşmiş Milletler Kalkınma Programı ve Birleşmiş Milletler Nüfus Fonu. (2005). "Türkiye'deki Namus Cinayetlerinin Dinamikleri Eylem Programı İcin Öneriler Sonuç Raporu”. Ankara.

CEDAW. (1992). Violence Against Women, General Recommendation 19. UN Doc., United Nations, 15. Vienna.

Connell, Raweyn (1998). Toplumsal Cinsiyet ve İktidar-Toplum, Kişi ve Cinsel Politika, Çev. C. Soydemir. İstanbul: Ayrıntı Yayınları.

Demirler, Derya \& Gümüş, Pınar (2004). "TCK Değişirken”, Bü'de Kadın Gündemi 7, www. feminisite.net. Erişim Tarihi: 05.05.2009.

Dursun, Çiler (2008). Kadına Yönelik Aile İçi Şiddet ve Haber Medyası: Alternatif Bir Habercilik, Kadının Statüsü Genel Müdürlüğü: Ankara.

Dursun, Çiler (2010). “Kadına Yönelik Şiddet Karşısında Haber Etiği. ” Fe Dergi 2(1): 19-32.

Gazioğlu, Elif (2013). Kadın Cinayetleri: Kavramsallaştırma ve Sorunlu Yaklaşımlar. Sosyal Politika Çalışmaları. T.C. Aile ve Sosyal Politikalar Bakanlığı Hakemli Araştırma Dergisi. Yıl: 13, 7(30) 30: 89-100.

Gencel Bek, Mine (2011). "Ataerkillik, Piyasa ve Mesleki Değerler: Medyada Aile İçi Şiddeti Temsili ve Üretim Pratikleri”. Bir Arpa Boyu içinde, Prof. Dr. Nermin Abadan Unat'a Armağan, (Der.) S. Sancar, İstanbul: Koç Üniversitesi Yayınları.

Gencel Bek, Mine \& Binark, Mutlu (2000a). Medyada Kadın, Ankara Üniversitesi Kasaum, www. kasaum.ankara.edu.tr/kasaumegitimaraclari.html. Erişim Tarihi: 09.10.2014

Gencel Bek, Mine \& Binark, Mutlu (2000b). Medya ve Cinsiyetçilik. Ankara: Kasaum Yayını.

Gökulu, Gökhan \& Hosta, Nilay (2013). "Basında Kadına Yönelik Şiddet Haberlerinin Analizi: Hürriyet, Sabah ve Posta Gazeteleri Örneği (2005-2008). " International Journal of Social Science. 6(2): 1829-1850.

Görgün Baran, Aylin (2012). Medyanın Kadına Yönelik Şiddet Olaylarına Yaklaşımı: Habercilik ve Diziler", İnsan Hakları Standartlarının Etkili Uygulanması Bağlamında Kadına Yönelik Şiddetle Mücadele Sempozyum Kitabı. Ankara: Türkiye Adalet Akademisi Yayınları.

Lundgren, Eva (2009). Şiddetin Normalleştirilme Süreci. Çev: B. Ekal. İstanbul: Rengahenk Sanatevi.

Işık, Ruşen \& Sakallı-Uğurlu, Nuray (2009). "Namusa ve Namus Adına Kadına Uygulanan Şiddete İlişkin Tutumlar Ölçeklerinin Öğrenci Örneklemiyle Geliştirilmesi. ” Türk Psikoloji Yazıları. 12 (24): 16-24. 
Irmak, Fatih (2014). "Türkiye'de Şiddet Suçlarının Sosyal Yapı ve Sosyal Sermayeye İlişki Bağlantıları". Şiddet Suçları, Yaklaşımlar, Trendlerin İçinde. Ed: Dr. Fatih Irmak \& Emirhan Darcan, Ankara: Adalet Yayınevi, ss. 65-82.

Illkkaracan, Pınar, Gülçür, Leyla \& Arın, Canan (1996). Sıcak Yuva Masalı: Aile İçi Şiddet ve Cinsel Taciz. İstanbul: Metis Yayınları.

İnci, Ülkü Hayriye (2013). Basında Yer Alan Namus Cinayetlerinin Sosyolojik Analizi. Tarih Kültür ve Sanat Araştırmaları Dergisi. 2 (3): 282-296. Erişim Tarihi: 07.10.2014

Kandiyoti, Deniz (1988). Bargaining With Patriarchy. Gender And Society. Special Issue To Honor Jessie Bernard. 2 (3): 274-290.

Kandiyoti, Deniz (1995). Ataerkil Örüntüler: Türk Toplumunda Erkek Egemenliğinin Çözümlenmesine Yönelik Notlar, Kadın Bakış Açısından 1980'ler Türkiye'sinde Kadın. Der . Şirin Tekeli. İstanbul: Illetişim Yayınevi. 367-382.

Kardam, Filiz (1999). Töre Cinayetleri Üzerine Bazı Düşünceler Töre Cinayetleri- Panel Bildiri Kitabı. Ankara: Türkiye Cumhuriyeti Devlet Bakanlığı Kadının Statüsü ve Sorunları Genel Müdürlüğü Yayınları.

Koğacıoğlu, Dicle (2004). "The Tradition Effect: Framing Honor Crimes in Turkey. "A Journal of Feminist Cultural Studies. 15 (2): 118-151.

Kümbetoğlu, Belkıs (2010). Namus Cinayetleri: Töre Değil Ataerki. Namus Cinayetleri: Töre Değil Ataerki İçinde, İstanbul: Kazancı Kitap. 75-102.

O'Leary, K. Daniel (1988). "Physical Aggression Between Spouses: A Social Learning Perspective, Handbook of Family Violence, (Der.) V. Hasselt ve diğerleri. New York, Plenum. http://www.Nova. Edu/Ssss/QR/QR5-1/Leavy.Html. Erişim 01.10.2013.

Ocak, Serkan (2012). "Doğan Yayın Holding, 13 yıllık 'Yayın İlkeleri'ni günün ihtiyaçlarına göre geliştirerek yeniledi. Yayın ilkeleri arasına sosyal medya da girdi http://www.radikal.com.tr/ turkiye/dogan yayindan yeni ilkeler-1111490; serkan.ocak@radikal.com.tr/arşiv). Erişim tarihi 10.02.2013.

Parla, Ayşe (2001) The 'Honor' Of The State: Virginity Examinations in Turkey. Feminist Studies. 27(1): 65-88.

Pervizat, Leyla, Sirman, Nükhet \& Mojab, Shahrzad. (2004). Violence in The Name Of Honour: Theoretical And Political Challenges. Ed. S. Mojab \& N. Abdo-Zubi. İstanbul: İstanbul Bilgi Üniversitesi Yayınları.

Saktanber, Ayşe (1995). "Türkiye'de Medyada Kadın: Serbest, Müsait Kadın veya İyi Eş," Kadın Bakış Açısından 1980'ler Türkiye'sinde Kadın. Der: Ş. Tekeli, İstanbul: İletişim Yayınevi. 211-232.

Sallan Gül, Songül (2013). "The Role Of The State in Protecting Women Against Domestic Violence And Women's Shelters in Turkey. "Women's Studies International Forum. May-June: 107-116. 
Sallan Gül, Songül (2011). Türkiye'de Kadın Sığınmaevleri Erkek Şiddetinden Uzak Yaşama Açılan Kapılar Mı? İstanbul: Bağlam Yayınları.

Sallan Gül, Songül \& Altındal, Yonca (2014). "Kadın Cinayetlerini Kadın Bakış Açısıyla Sorgulamak. " Şiddet Suçları, Yaklaşımlar, Trendlerin İçinde, Ed: Dr. F. Irmak \& E. Darcan, Ankara: Adalet Yayınevi. 193-222.

Shaw, Clifford R. \& McKay, Henry D (1972). Juvenile Delinquency and Urban Areas: A Study of Rates of Delinquency in Relation to Differentiatial Characteristics of Local Communities in American Cities. Chicago: University of Chicago Press.

SASRN (2012). Femicide: A Global Problem, Commission On Crime Prevention and Criminal Justice, Small Arms Survey Research Notes Small Arms Survey Research Notes Academic Council on the United Nations System, Twentyfirst session. February 2012, 2327, (14).

Snell, Clete (2001). Neighborhood Structure, Crime, And Fear Of Crime: Testing Bursik And Grasmick's Neighborhood Control Theory. NY: Lfb.

Spinelli, Barbara (2011) Femicide And Feminicide In Europe, Gender-Motivated Killings Of Women As A Result of Intımate Partner Violence, Expert Group Meeting On Gender-Motivated Killings of Women, Organized by the UN Special Rapporteur on Violence Against Women. New York, 12 October 2011.

Şen, Ersan (2006). Yeni Türk Ceza Kanunu Yorumu. Cilt 1 (1). Baskı, İstanbul: Vedat Kitapçllık. 261.

Timisi, Nilüfer (1997). Medyada Cinsiyetçilik, T.C. Başbakanlık Kadının Statüsü ve Sorunları Genel Müdürleri: Ankara.

Türkiye Büyük Millet Meclisi İnsan Haklarını Inceleme Komisyonu (2011). Kadın Ve Aile Bireylerine Yönelik Şiddet İnceleme: Ankara.

KSGM. 2006. "Töre ve Namus Cinayetleri ile Kadınlara ve Çocuklara Yönelik Şiddetin Sebeplerinin Araştııılarak Alınması Gereken Önlemlerin Belirlenmesi Amacıyla Kurulan TBMM Araştırma Komisyonu Raporu", T.C. Başbakanlık Kadının Statüsü Genel Müdürlüğü : Ankara.

KSGM. 2008. Kadın ve Medya, T.C. Başbakanlık Kadının Statüsü Genel Müdürlüğü, Ankara.

Leavy, Patricia Lina (2000). "Feminist Content Analysis And Representative Characters. " The Qualitative Report [On-Line Serial]. 5 (1/2).

Tezcan, Mahmut. 1999. "Ülkemizde Aile İçi Töre Ya Da Namus Cinayetleri”. T.C. Başbakanlık Kadının Statüsü ve Sorunları Genel Müdürlüğü. Ankara: T.C. Başbakanlık Kadının Statüsü ve Sorunları Genel Müdürlüğü. 21-27.

Vito, Gennaro F., \& Holmes, Ronalds. 1994. Criminology, Theory, Research and Policy. International Thomson Pub.: Belmont/California.

Walby, Slyia. 1990. Theorizing Patriarchy. Oxford, Cambridge: Blackwell. 
WHO. 2002. World Report on Violence and Health. World Health Organization, Geneva.

Yıldırım, Aysel. 1998. Sıradan Şiddet Kadına Ve Çocuğa Yönelik Şiddetin Toplumsal Kaynakları. İstanbul: Boyut Yayınları.

Yirmibeşoğlu, Vildan. 1997. Compilation Of Newspaper Articles On Honor Killings. Presented To Women For Women's Human Rights, İstanbul.

www. kadincinayetlerinidurduracagizplatformu.org. Erişim Tarihi: 12.10.2014 
WHO. 2002. World Report on Violence and Health. World Health Organization, Geneva.

Yıldırım, Aysel. 1998. Sıradan Şiddet Kadına Ve Çocuğa Yönelik Şiddetin Toplumsal Kaynakları. İstanbul: Boyut Yayınları.

Yirmibeşoğlu, Vildan. 1997. Compilation Of Newspaper Articles On Honor Killings. Presented To Women For Women's Human Rights, İstanbul.

www. kadincinayetlerinidurduracagizplatformu.org. Erişim Tarihi: 12.10.2014 